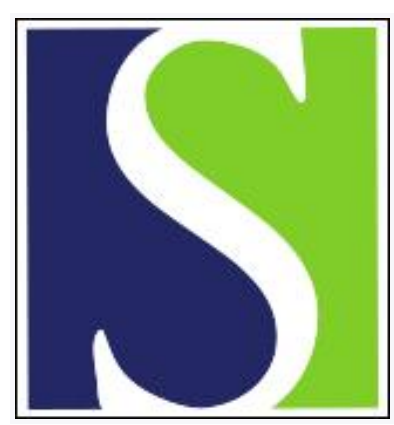

Scand J Work Environ Health 1991;17(1):75-78

https://doi.org/10.5271/sjweh.1730

Issue date: Feb 1991

Measurement of organic halogen compounds in urine as an indicator of exposure.

by Salkinoja-Salonen MS, Jokela JK

Affiliation: Department of General Microbiology, University of Helsinki, Finland.

This article in PubMed: www.ncbi.nlm.nih.gov/pubmed/2047811

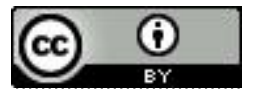




\title{
Measurement of organic halogen compounds in urine as an indicator of exposure
}

\author{
by Mirja S Salkinoja-Salonen, $\mathrm{PhD}$, Jouni K Jokela, $\mathrm{MSc}^{1}$
}

\begin{abstract}
SALKINOJA-SALONEN MS, JOKELA JK. Measurement of organic halogen compounds in urine as an indicator of exposure. Scand J Work Environ Health 1991;17:75-8. The report describes the measurement of urinary organic halogen compounds. The method is an application of the adsorbable organic halogen assay which is widely used for the analysis of industrial waste water and drinking water. It was found that this assay can be applied to human urine if the urine is pretreated to hydrolyze the mucins so as to cleave the neuraminic acid residues responsible for the high viscosity of these slimy proteins. The method was found to be sensitive down to $1 \mu \mathrm{g}$ of organic halogen $/ 100 \mathrm{ml}$ of urine. Fifty to $260 \mu \mathrm{g}$ of organic halogen was measured in the night urine of healthy, occupationally unexposed volunteers. Since many toxic chemicals to which man may be exposed environmentally or occupationally are, in fact, halogen compounds, this assay may be used to monitor for human exposure.
\end{abstract}

Key terms: adsorbable organic halogen, excreted, pollutant.

The majority of all hazardous man-made chemicals contain organically bound chlorine or bromine. This group covers most pesticides and herbicides $(1-3)$ and many antimicrobial agents (4-6) and widely utilized industrial solvents $(1,7-10)$ that frequently cause occupational poisoning $(1,6-10)$ and pollute ground water $(1,11)$. Sixteen out of the 18 organic chemicals, for which the maximal allowable concentration recommended by the World Health Organization at the partsper-billion (micrograms/liter) level in drinking water are also organic chlorine compounds (12).

The extent to which man is actually exposed to chemicals from the environment is poorly documented. Suitable methods are lacking to analyze the diverse chemicals in any large group of persons. Modern analytical methods, like gas chromatography-mass spectrometry, give accurate results but are costly and require personnel with specific skills. This paper describes the measurement of organic halogen compounds in human urine by microcoulometric titration after adsorption to activated carbon and combustion into hydrogen halides. It is not labor intensive and can be applied to large numbers of urine samples. It is group-specific rather than compound-specific and may thus have potential use for monitoring human exposure to a wide spectrum of chemicals in the environment and in the workplace.

\footnotetext{
${ }^{1}$ Department of General Microbiology, University of Helsinki, Helsinki, Finland.

Reprint requests to: Dr M Salkinoja-Salonen, Department of General Microbiology, University of Helsinki, Mannerheimintie 172, SF-00300 Helsinki, Finland.
}

\section{Materials and methods}

\section{Collection and pretreatment of urine samples}

The entire amount of night urine was collected from the subjects. If the urine could not be analyzed on the same day, the $\mathrm{pH}$ was adjusted to $\leq 5$ with nitric acid.

Before the analysis the urine was pretreated to desialinate the urine-contained mucins (sialic acid containing mucoproteins) either with neuraminidase $\left(0.01 \mathrm{U} / 50 \mathrm{ml}\right.$ of urine, $>2 \mathrm{~h}$ at $37^{\circ} \mathrm{C}, \mathrm{pH} 4$ to 5 , adjusted with nitric acid) or mild acid hydrolysis at $\mathrm{pH} 1.3$ (nitric acid) for $1 \mathrm{~h}$ at room temperature. The urine was then diluted to $1000 \mathrm{ml}$ or the desired density $\left(1.024 \mathrm{~g} / \mathrm{cm}^{3}\right)$ with pure water [adsorbable organic halogen (AOX) contents $<5 \mu \mathrm{g} / \mathrm{l}$; see the section on chemicals and glassware].

\section{Analysis of organic halogen}

Aliquots of $50 \mathrm{ml}$ of the pretreated (diluted) urine in triplicate were placed in conical flasks of $250 \mathrm{ml}$ together with sodium nitrate $(0.85 \mathrm{~g}$ in $5 \mathrm{ml}$ of water) and activated carbon $(50 \mathrm{mg})$. The flasks were closed with teflon-lined screw caps, placed in a gyratory shaker for $1 \mathrm{~h}$ or longer (up to overnight) and processed further as described in the standard protocols for determining AOX in water or waste water (13-15).

After incubation, the activated carbon was collected on polycarbonate filter and the AOX measured, after removal of the inorganic chloride (13-15), with the use of the microcoulometric analyzer of Euroglass BV (Delft, The Netherlands), equipped with an automated sample feeder.

\section{Chemicals and glassware}

To maintain a low reagent background, pure water (with an AOX content of $<5 \mu \mathrm{g} / \mathrm{l}$ ) was used for 
preparing the reagents and (optional) diluting of the urine. Since common laboratory cleaning agents may contain halogenated disinfectant, only disposable glassware should be used, or the glassware should be washed separately from other laboratory routines. We cleaned with ethanolic potassium hydroxide and rinsed with dilute nitric acid, ethanol, and pure water.

Activated carbon was obtained from Euroglass BV, the polycarbonate filters $(0.2 \mu \mathrm{m})$ from Nuclepore, and the neuraminidase (EC 3.2.1.18) from Sigma.

The pesticides and their parent compounds used in this study were as follows: aldrin (HHDN, 1,2,3,4, 10,10-hexachloro-6-7-epoxy-1,4,4a,5,6,7,8,8a-octahydroendo-1,4,-exo-5,8-dimethanonaphthalene, Riedelde Haen AG D-3016, Selcze, Germany), 3,5-dichloroaniline (Ishihara Sangyo Kaisha Ltd, Japan), quintozene (pentachloronitrobenzene, Kasei Organic Chemicals, Tokyo), trichloroacetic acid (E Merck, Darmstadt, Germany), 2,4,5-trichlorophenol and pentachlorophenol (Fluka AG, Buchs, Switzerland). The disinfectants were dichlorophene (2,2'-methylene-bis4-chlorophenol, Givaudan Corporation, Clifton, New Jersey, United States) and Irgasan DP-300 (2,4,4'trichloro-2'-hydroxydiphenyl ether, Bayer AG, Leverkusen, Germany). The industrial solvents were 1,2-dichlorobenzene (Fluka AG) and 1,1,1-trichloroethane (Rathburn Chemicals Ltd, Walkerburn, United Kingdom). The following pesticides and slimicides were ob- tained as technical products from the suppliers to the local industry: 2,4-D [(2,4-dichlorophenoxy) acetic acid], DBNPA (2,2-dibromo-3-nitrilopropionamide), and 1,4-bis-bromoacetoxy-2-butene.

For testing the recovery, these chemicals were dissolved in urine to $5-20 \mu \mathrm{g}$ of organic halogen (stock solution on ethanol or tetrahydrofuran) per $50 \mathrm{ml}$.

\section{Results}

We used the microcoulometric assay to measure the contents of organically bound halogen in human urine. The filterability of human urine through the polycarbonate was poor, and therefore the removal of inorganic halides was incomplete at the nitrate wash, and thus the results were unreliable (too high).

The filterability of urine was dramatically improved upon preincubation of the urine with neuraminidase. The filtration time required for $50 \mathrm{ml}$ of urine was decreased by this treatment from $2-5 \mathrm{~h}$ to $10 \mathrm{~min}$ or less (ie, a time comparable to that for clear water samples). The same effect was achieved by mild acid hydrolysis of the urine $(\mathrm{pH} \leq 1.5)$.

We tested the halogen recovery of a variety of different organic halogen compounds in urine. The results, recorded in figure 1 , showed that, of the 15 chemicals tested, 12 were measured with good recovery ( $>70 \%$ for concentrations of 0.2 to $10 \mu \mathrm{M}$ ) in

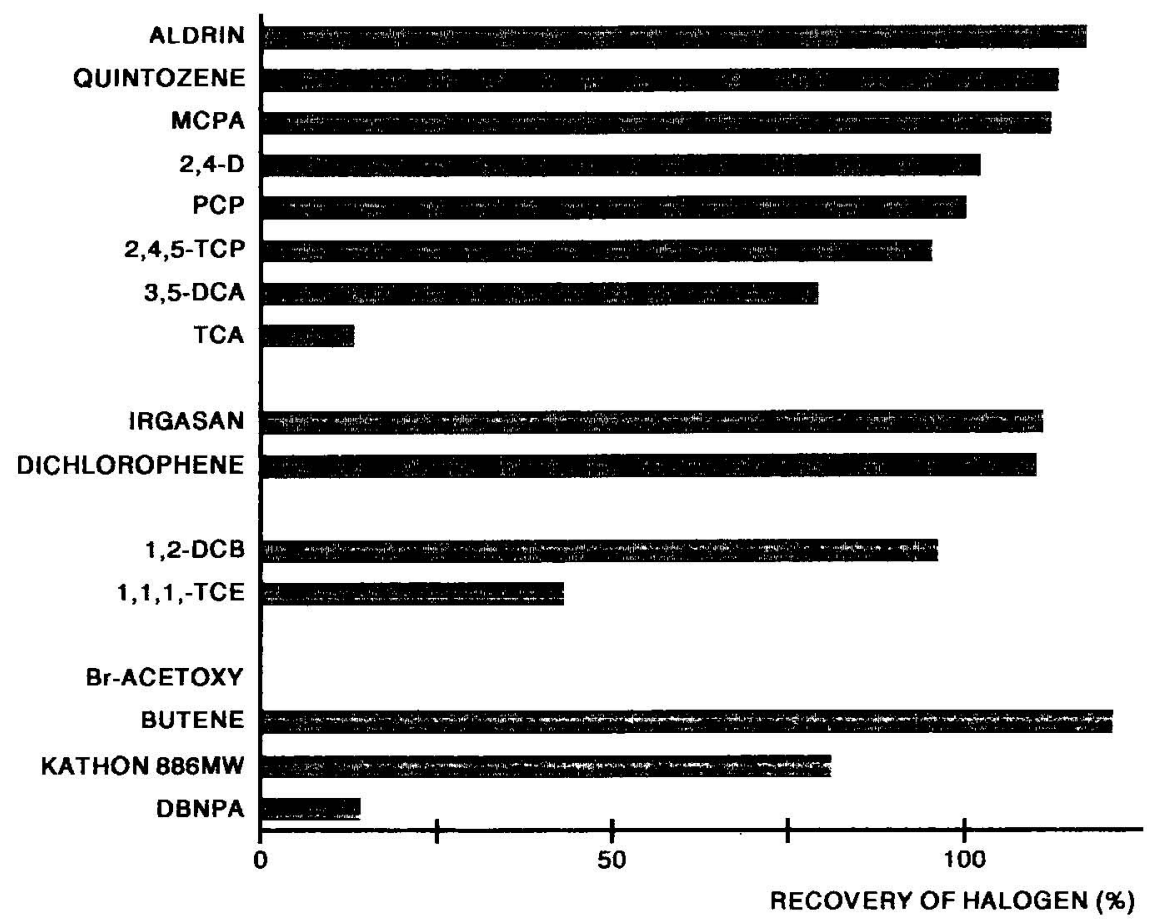

Figure 1. Measurement of organic halogen compounds in urine by the adsorbable organic halogen (AOX) assay. The recovery of halogen from 15 selected pesticides, disinfecting agents, industrial solvents, and slimicides, present in concentrations of $0.2-10 \mu \mathrm{M}$, are shown in the figure. [MCPA = (4-chloro-2-methyl)-phenoxy acetic acid; 2,4-D = 2,4-dichlorophenoxy acetic acid; $\mathrm{PCP}=$ pentachlorophenol; 2,4,5-TCP $=2,4,5$-trichlorophenol; 3,5-DCA = 3,5-dichloroaniline; $\mathrm{TCA}=$ trichloroacetic acid; 1,2 -DCB = 1,2-dichlorobenzene; 1,1,1-TCE = 1,1,1-trichloroethane; Br-acetoxy butene =1,4-bis bromoacetoxy-2-butene; Kathon 886MW= 5-chloro-2-methyl-3(2H)isothiazolone; DBNPA = 2,2-dibromo-3-nitrilopropionamide] 
urine when a hydrolysis or neuraminidase step was included in the standard AOX protocol. The results show that other organic compounds (urea, uric acid, creatinine, bilirubins) in the urine did not seriously interfere with the assay of the organic halogen compounds.

The AOX content of urine was measured from occupationally unexposed volunteers $(\mathrm{N}=51$, aged 2-79 years) in Finland. No clear-cut correlation of the urine AOX content with age, sex, or body weight was found. Unexpectedly, our results suggested regional variation. Figure 2 shows examples of results obtained from residents of the Helsinki metropolitan area and those from a small, heavily industrialized town $300 \mathrm{~km}$ east of Helsinki. The individual variation of the AOX contents of night urine from the residents of Helsinki ranged from 50 to $90 \mu \mathrm{g}$ (average: males $71 \mu \mathrm{g}$, females $62 \mu \mathrm{g}$ ) and at Imatra from 60 to $190 \mu \mathrm{g}$ (average: males $132 \mu \mathrm{g}$, females $105 \mu \mathrm{g}$ ).

Since one very obvious exposure route of humans to organic halogen compounds is drinking water, the AOX contents of both urine and tap water were measured at six different localities in Finland. The results, depicted in figure 3 , indicated a positive correlation between the urinary AOX and the AOX in tap water.

\section{Discussion}

The measurement of AOX has been shown to be a valuable tool for monitoring potable water quality (13, 15-17) and undesirable waste-water discharges from industry (14). In this paper we show that it is possible to adapt this method to the monitoring of $\mathrm{AOX}$ in human urine.

The filterability of untreated urine was poor, causing the AOX assay to fail, unless modified to remove viscosity caused by mucins excreted by the mucous membranes of the urinary tract. The desired effect was obtained with either neuraminidase or mild acidolysis. Both treatments are known to remove neuraminic acid residues from the mucins $(18,19)$. Mucins are extremely viscous, rod-shaped molecules, but lose their viscosity when the terminal neuraminic acid residues of their polysaccharide moieties are removed (18).

We found satisfactory recovery for many different randomly selected pesticides, disinfectants, industrial solvents, slimicides, and fungicides (figure 1), chosen as representatives of chemicals to which humans may be exposed occupationally or environmentally. The AOX assay was sufficiently sensitive to detect these chemicals in the urine at the same concentration recommended by the World Health Organization as the acceptable limit in drinking water $(1 \mu \mathrm{g}$ of organic halogen $/ 100 \mathrm{ml}$ ) (12). The preliminary results of this work have been reported elsewhere (20).

There was a positive correlation between the urinary AOX contents and those of the residential drinking water (figure 3 ). This finding may indicate that a significant share of the AOX contained in the drinking

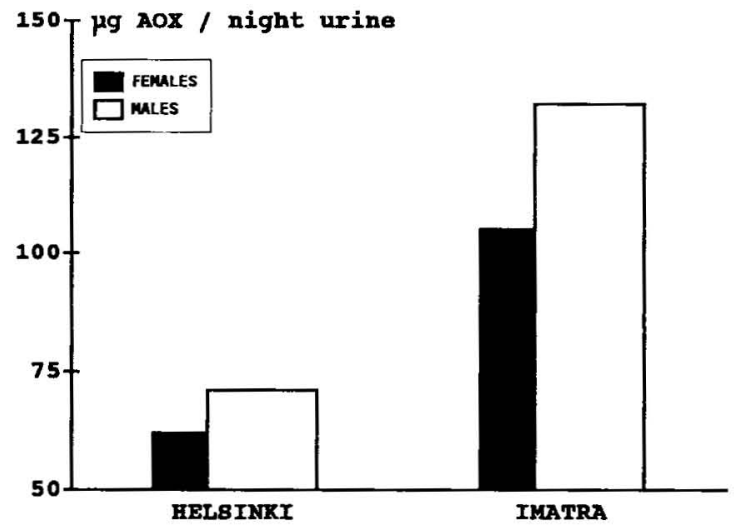

Figure 2. Levels of organic halogen compounds measured as adsorbable organic halogen (AOX) in the urine of occupationally unexposed volunteers.

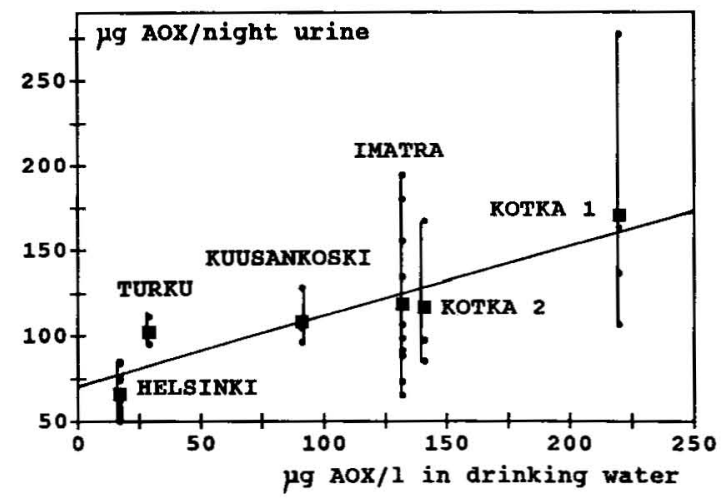

Figure 3. Correlation between the adsorbable organic halogen $(A O X)$ concentration in urine and drinking water from different localities. The samples were collected in January-March 1990 in five different towns. All five used surface water to make drinking water. In Helsinki ozone followed by light chlorination was used for disinfection; in the other localities chlorination only was used. The tapwater and the urine were collected on the same day. (Kotka $1=$ January 1990, Kotka $2=$ March 1990)

water was actually resorbed by the gastrointestinal tract and then renally excreted by the studied individuals. Organic halogen compounds in drinking water disinfected with chlorine have been shown to be mutagenic and are suspected of being carcinogenic $(21-25)$. In Finland the AOX content of drinking water is very high because of the chlorine disinfection used for humic raw water $(24,25)$.

Human metabolism is not known to synthesize organic halogen compounds, apart from the iodinecontaining hormone thyroxine. If the data in figure 3 are extrapolated to $0 \mu \mathrm{g}$ of $\mathrm{AOX} / \mathrm{I}$ of drinking water, there remains a residual $\mathrm{AOX}$ in the urine of around $70 \mu \mathrm{g}$. It remains to be seen how much of this amount originates from thyroxine turnover and what is the role of airborne exposure and food.

In our opinion, the analysis of urinary AOX will be a useful tool for monitoring human exposure to chem- 
icals at the workplace and in the environment. It only takes $10 \mathrm{~min}$ to perform, after $1 \mathrm{~h}$ of mucin hydrolysis of urine and $1 \mathrm{~h}$ for adsorption onto activated carbon has been allowed for. The analysis procedure is simple, requires no costly reagents, and one laboratory person can handle 20 to 30 samples per workday. The method may thus be applied to large populations.

\section{Acknowledgments}

This study was made possible by financial support from the Finnish Work Environment Fund, the Maj and Tor Nessling Foundation and the Academy of Finland.

Ms $\mathbf{R}$ Boeck contributed substantially to the experimental part of this work. We also thank Ms E Elomaa and $\mathrm{Mr} \mathrm{R}$ Hamari for their help in organizing the collection of urine from the volunteers.

\section{References}

1. World Health Organization. Guidelines for drinkingwater quality; vol 2 (Health criteria and other supporting information). Geneva: World Health Organization, 1984:162-239.

2. Worthing CR, Walker SB, ed. The pesticide manual. 7th ed. Lavenham: Lavenham Press Ltd, 1983.

3. International Programme on Chemical Safety. 2,3-Dichlorophenoxyacetic acid: environmental aspects. Geneva: World Health Organization, 1989. (Environmental health criteria 84.)

4. Block SS. Disinfection, sterilization and preservation: antiseptics and disinfectants. Philadelphia, PA: Lea \& Febiger, 1983:157-308.

5. McCoy JW. Microbiology of cooling water. New York, NY: New York NY Chemical Publishing Co, 1980: 73-107.

6. International Programme on Chemical Safety. Pentachlorophenol. Geneva: World Health Organization 1986. (Environmental health criteria 71.)

7. International Programme on Chemical Safety. Tetrachloroethylene. Geneva: World Health Organization, 1984. (Environmental health criteria 31.)

8. International Programme on Chemical Safety. Trichloroethylene. Geneva: World Health Organization, 1986. (Environmental health criteria 50.)

9. Böttger A. Die Wirkung von Tetrachloräten auf Beschäftigte in Chemisch-Reinigung. Umwelthygiene, Jahresbericht 1987/88. Duesseldorf: Gesellschaft zur Forderung der Lufthygiene und Silikoseforschung eV, $1988 ;(20): 56-76$.

10. McCunney RJ. Diverse manifestations of trichloroethylene. $\mathrm{Br} \mathrm{J}$ Ind Med 1988;45:122-6.

11. Zoeteman BCJ. Overview of contaminants in ground water. In: Ward, CH, Giger W, McCarthy PL, ed.
Ground water quality, New York \& Chichester: Wiley Interscience, 1985:27-38.

12. World Health Organization. Guidelines for drinkingwater quality; vol 1 (Chemical and physical aspects: recommendations). Geneva: World Health Organization, 1984:47-102.

13. Deutsche Einheitsverfahren. Summarische Wirkungsund Stoffkenngrössen (Gruppe $\mathrm{H}$ ). Bestimmung der adsorbierbaren organisch gebundenen Halogene (AOX). Berlin: Deutsches Institut für Normung, 1985. (DIN 38409 (Teil 14).

14. Anonymous. Effluents from pulp mills: organically bound chlorine by the AOX method. Stockholm: Scandinavian Pulp, Paper and Board Testing Committee, 1989. (SCAN-W 9:89.)

15. International Organization for Standardization. Water quality - determination of adsorbable organic halogens (AOX). Geneva: International Organization for Standardization, 1989. (ISO 9562.)

16. Stevens AA, Dressman RC, Sorrel RK, Brass HJ. TOX is the non-specific parameter of the future. Cincinnati, $\mathrm{OH}$ : Environmental Protection Agency, 1984. (EPA600/D-84-169.)

17. European Community Environmental Legislation. Council directive of 15 July 1980 relating to the quality of water intended for human consumption. Brussels: European Community Environmental Legislation, 1980. (80/778/EEC.)

18. Sharon N. Complex carbohydrates: their chemistry, biosynthesis and functions. London \& Amsterdam: Addison-Wesley Publishing Company, 1975:49-63 \& 17792.

19. Neuberger A, Marshall RD. Methods for the qualitative and quantitative analysis of the component sugars. In: Gottschalk A, ed. Glycoproteins: their composition, structure and function. Amsterdam: Elsevier Publishing Company, 1966:190-234.

20. Salkinoja-Salonen MS, Jokela JK, Boeck R, Al-Soufi $\mathrm{K}$. Halogeeniyhdisteet ymparistossa ja ihmisessa. [Halogen compounds in the environment and man]. Työterveyslääkäri 1990;8(2):26-9.

21. Maruoka S, Yamanaka S. Comparative studies using the Ames Salmonella/microsome test on mutagenicity of the $\mathrm{XAD}$ extract recovered from the river in Kyoto City. Environ Sci Technol 1983;17:177-80.

22. Meier JR, Ringhand HP, Coleman WE, et al. Mutagenic by-products from chlorination of humic acid. Environ Health Perspect 1986;69:101-7.

23. Kool HJ, Kuper F, Van Haeringen H, Koeman JH. A carcinogenicity study with mutagenic organic concentrates of drinking water in the Netherlands. Food Chem Toxicol 1985;23(1):79-85.

24. Kronberg L. Holmbom B, Tikkanen L. Fractionation of mutagenic compounds formed during chlorination of humic water. Sci Total Environ 1985;47:343-7.

25. Vartiainen $T$. Mutagenicity of drinking waters in Finland. Helsinki: National Public Health Institute, 1988. (A2/1988).

Received for publication: 17 May 1990 